\title{
Regulated Efficiency, World Trade Organization Accession, and the Motor Vehicle Sector in China
}

\author{
Joseph F. Francois and Dean Spinanger
}

\begin{abstract}
This article is concerned with the interaction of regulated efficiency and World Trade Organization (พTO) accession and its impact on China's motor vehicle sector. The analysis is conducted using a 23 sector- 25 region computable general equilibrium model. Regulatory reform and internal restructuring are found to be critical. Restructuring is represented by a cost reduction following from consolidation and rationalization that moves costs toward global norms. Without restructuring, WTO accession means a surge of final imports, though imports of parts could well fall as production moves offshore. However, with restructuring, the final assembly industry can be made competitive by world standards, with a strengthened position for the industry.
\end{abstract}

Producing automobiles has often been a symbol of economic prestige in the developing world. Brazil, China, Indonesia, Malaysia, and others have all promoted and sometimes even showcased the development of a domestic motor vehicle industry. In China, with its huge population and a surface area roughly as large as the United States and almost 15 percent larger than Brazil (table 1), almost every province has its own motor vehicle factory and satellite factories. But despite all the factories, China has the largest number of people per vehicle among major economies in the world. Even Indonesia, with a 30 percent lower per capita income, has only half as many people per automobile.

China's status as a country with one of the highest number of people per vehicle is the outcome of a series of policy measures, dating as far back as the inception of the People's Republic of China, that have distorted the structure of the automobile industry (table 2). Internal measures limited and even prohibited trade through local protectionism (analogous to former interprovincial trade restrictions in Canada). The government has also set prices and limited competition through a barrage of import restrictions, which have included

Joseph F. Francois is professor of economics and research fellow at the Tinbergen Institute and research fellow at the Centre for Economic Policy Research; his e-mail address is francois@few.eur.nl. Dean Spinanger is senior research economist at the Institute for World Economies in Kiel; his e-mail address is dspinanger@ifw.uni-kiel.de. The authors thank Zhang Wenkui for help with data, Will Martin and Alan Winters for detailed comments on an earlier draft, and three anonymous referees who offered valuable suggestions. They also thank participants in a World Bank-sponsored conference in Beijing for helpful discussion.

THE WORLD BANK ECONOMIC REVIEW, VOL. 18, NO. 1,

(C) The International Bank for Reconstruction and Development / THE WORLD BANK 2004; all rights reserved. DOI: $10.1093 /$ wber/lhh034

18:85-104 
Table 1. GNP, Population, and Stocks of Automobiles in China and Selected Countries, 2000

\begin{tabular}{|c|c|c|c|c|c|c|}
\hline \multirow[b]{2}{*}{ Economy } & \multirow{2}{*}{$\begin{array}{l}\text { GNP per } \\
\text { capita } \\
(2002 \\
\text { PPP \$) }\end{array}$} & \multirow{2}{*}{$\begin{array}{c}\text { Population, } \\
2001 \\
\text { (millions) }\end{array}$} & \multicolumn{2}{|c|}{$\begin{array}{l}\text { Vehicle stock, } \\
2001 \text { (millions) }\end{array}$} & \multirow{2}{*}{$\begin{array}{l}\text { People per } \\
\text { automobile }\end{array}$} & \multirow{2}{*}{$\begin{array}{c}\text { Surface area } \\
(1,000 \text { sq. } \mathrm{km})\end{array}$} \\
\hline & & & Automobiles & Trucks & & \\
\hline $\begin{array}{l}\text { Low and middle } \\
\text { income }\end{array}$ & 4,682 & $3,274.4$ & 140.6 & 54.9 & 23.3 & 49,263 \\
\hline India & 2,570 & $1,032.4$ & 6.3 & 5.9 & 163.2 & 3,287 \\
\hline Indonesia & 2,990 & 209.0 & 3.0 & 2.4 & 68.8 & 1,905 \\
\hline China & 4,390 & $1,271.8$ & 8.5 & 15.4 & 149.0 & 9,598 \\
\hline Colombia & 5,870 & 43.0 & 1.8 & 0.8 & 23.4 & 1,139 \\
\hline Turkey & 6,120 & 66.2 & 4.5 & 1.6 & 14.6 & 775 \\
\hline Thailand & 6,680 & 61.2 & 2.9 & 4.1 & 21.4 & 513 \\
\hline Brazil & 7,250 & 172.4 & 15.8 & 4.0 & 10.9 & 8,547 \\
\hline Russia & 7,820 & 144.8 & 21.2 & 5.1 & 6.8 & 17,075 \\
\hline Malaysia & 8,280 & 23.8 & 4.2 & 1.0 & 5.6 & 330 \\
\hline Mexico & 8,540 & 99.4 & 12.2 & 5.6 & 8.2 & 1,958 \\
\hline South Africa & 9,870 & 43.2 & 41.0 & 2.5 & 1.1 & 1,221 \\
\hline Argentina & 9,930 & 37.5 & 5.4 & 1.6 & 7.0 & 2,780 \\
\hline High income & 29,248 & 742.7 & 351.6 & 129.4 & 2.1 & 21,937 \\
\hline Korea, Rep. of & 16,480 & 47.3 & 8.9 & 4.0 & 5.3 & 99 \\
\hline Taiwan, China & 17,730 & 22.4 & 4.8 & 0.9 & 4.6 & 36 \\
\hline Spain & 20,460 & 41.1 & 18.2 & 4.2 & 2.3 & 506 \\
\hline Italy & 25,320 & 57.9 & 33.2 & 3.8 & 1.7 & 301 \\
\hline United Kingdom & 25,870 & 58.8 & 27.8 & 3.4 & 2.1 & 243 \\
\hline Japan & 26,070 & 127.0 & 53.5 & 19.9 & 2.4 & 378 \\
\hline France & 26,180 & 59.2 & 28.7 & 5.9 & 2.1 & 552 \\
\hline Germany & 26,220 & 82.3 & 44.4 & 3.6 & 1.9 & 357 \\
\hline Canada & 28,070 & 31.1 & 17.1 & 0.7 & 1.8 & 9,971 \\
\hline United States & 35,060 & 285.3 & 128.7 & 88.0 & 2.2 & 9,629 \\
\hline
\end{tabular}

${ }^{\text {apPP }}$ is purchasing power parity.

Source: World Bank, various years, World Development Indicators; Verband der Automobilindustrie, various issues.

quotas, high tariffs, and differential taxes favoring local suppliers. The restrictions on trade have encouraged inefficient production and allowed for market segmentation.

China's integration into the World Trade Organization (WTO), and thus into most favored nation principles, has important implications for its economy, especially the motor vehicle sector. Accession agreements define major changes in tariffs, quotas and local content requirements, and rules on foreign investment. There has already been a change in market perceptions by outside investors, as the application of WTO rules on treatment of foreign firms has reduced uncertainty about the general economic climate, inducing notable increases in investment and prompting new decisions about entering the market. 
Table 2. Summary of Developments in the Chinese Automotive Sector

Period Characteristics

1953-65: Self-reliance policy

1966-80: Security oriented

1981-98: Initial fruits of open-door policy

1999-present: opening up and beyond
Roughly 60,000 vehicles produced per year.

Relied on Soviet technologies.

No other international contacts.

Provincial governments set up production units.

By 1960,16 auto producers and 28 assembly companies.

Government invested heavily in western regions (Sichuan, Shanxi, and Hubei).

Remote locations caused severe problems and overcapacity.

Focus on heavy military vehicles.

Car demand increased rapidly and capacities expanded to 160,000 units a year.

By 1980, 58 carmakers, 192 assembly companies, and 2,000 spare parts producers.

Open-door policy in 1978 kick-started industry.

VW already started in 1978.

Number of companies almost doubled during 83-85, from 65 to 114 units.

By 1998 , roughly 2,500 production units.

Provincial governments further regionalized production.

Major international firms begin to invest and then stop rapidly.

Joint ventures accounted for about 60 percent of production.

Major investments by foreign companies.

All major Japanese and German companies in China.

French, Italian, and U.S. producers nominally present.

Rapid expansion; capacity now near 2.5 million units.

Growing capacity in costal areas.

Source: Summary produced by authors from various sources.

This article is concerned with the impact of these broad changes on the Chinese motor vehicle sector. It emphasizes the role of administratively imposed inefficiencies ("regulated efficiency") within the sector and the role of such regulated efficiency in structural adjustment. The industry itself anticipates significant change. In recent years the sector has grown rapidly, with output expanding at an annualized rate of 13 percent in the four years ending in 1999, at a rate of 26 percent in the three years to 2002, and at more than double that in 2003. With modern plants having come on line in 2001 and 2002, and 
additional facilities expected to increase capacity by more than 150 percent from 2002 to 2005, a large, discrete change in production levels is expected.

At the same time, WTO membership implies lower prices and steeper foreign competition in the sector. Response to this shift in the competitive landscape will be shaped by continuing problems with local government protection, lack of automobile infrastructure (roads, parking, service facilities), and related factors that act as constraints on growth of the sector. Even so, the industry itself expects continued strong growth. ${ }^{1}$

Notwithstanding industry expectations, what can realistically be expected once the competitive landscape has changed in critical ways? This question is explored here using a computable general equilibrium (CGE)model.

\section{The Automobile Industry in China}

National and regional policies in China have resulted in a highly fragmented and inefficient motor vehicle industry by global standards. This was not only the result of the introduction of Soviet-style industrialization beginning in the 1950s, with firms viewed merely as production units producing according to plan, making questions about efficiency irrelevant. ${ }^{2}$ It was also the result of import substitution policies and cooperation agreements with foreign companies beginning in the 1980s that were meant to fill the increasing gap between supply and rapidly expanding demand for automobiles. The major thrust of policies was to build trucks, not passenger cars (figure 1).

Motor vehicle companies are thus operating with cost structures that are well within the global frontier, with plants that are producing considerably below global standards for efficient scale (table 3). For plants producing a single model, minimum efficient scale for final assembly of cars has been estimated

1. See, for example, China Online (2000). As wTo membership approached, the opinions of the industry and related ministries, as reflected in the Chinese press, hinged critically on whether restructuring of the domestic industry would be allowed to proceed. Thus a report in Touzi Yu Hezuo (summarized in China Online 2000) stressed expected injury to the industry, whereas the industry itself was expressing optimism that it could realize significant cost reductions and remain competitive with imports (Feenstra and others 2001). In the meantime, price cuts by foreign producers in China are becoming common, some of them induced by increased import competition and others by more intense domestic competition. Buick, for instance, reduced prices on its domestically produced models by 12 percent, and Volkswagen lowered Passat prices by 6.5 percent (indiacar.net, May 3, 2002). Even more important, nearly all major foreign producers have announced plans to establish or sizably increase production capacities. A recent major manufacturer to do so was DaimlerChyrsler in September 2003, finally ratifying plans to establish facilities to produce C and E models in China (International Herald Tribune, September 9, 2003).

2. As noted by Zhang and Taylor (2001, pp. 261ff.), First Automobile Works (FAW) provides ample evidence of the impact of various policies over the past 50 years. Between 1959 and 1981 FAW produced a mere 1,542 units, an average 67 units annually. In 1970 the production cost of a particular model (the CA72) was 220,000 yuan, but "the sales price was only 40,000 yuan. ... In the absence of competition, all production units ran at low levels of productivity and efficiency. ... By 1980 the number of automotive enterprises had risen to 2,379 , consisting of 56 vehicle manufacturers ... [producing] 5,418 cars." 
Figure 1. China's Production of Motor Vehicles, 1984-2002 (thousands)

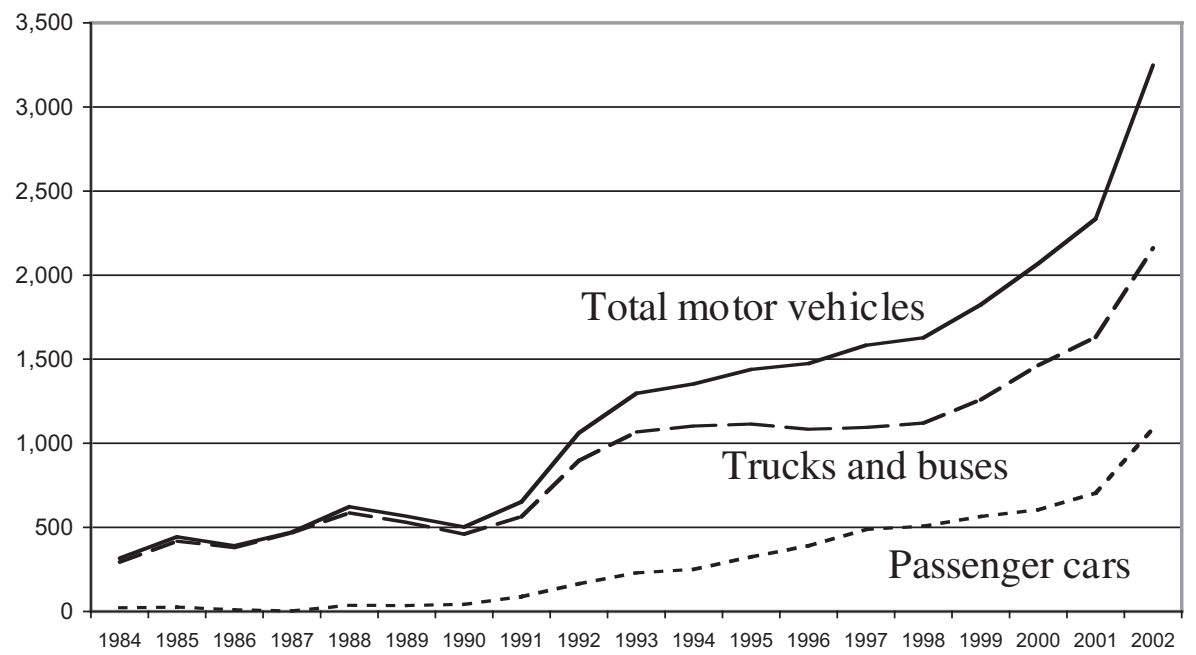

Source: Bessum (2002) and Verband der Automobilindustrie (various issues).

at more than 200,000 units per plant per year (Huang 2002, p. 543). China's entire sedan production in 1998 was 507,000 vehicles produced in 13 factories. Of these, only one factory produced more than 200,000 sedans.

Several plants had production runs of fewer than 20,000 sedans. ${ }^{3}$ In 1998 China had 122 motor vehicle manufacturing plants, 520 automobile refitting factories, 130 motorcycle factories, 62 car engine factories, and 1,589 automobile and motorcycle spare parts factories. Annual production capacity now exceeds 2.3 million motor vehicles and 10 million motorcycles. Since 1995 the general pattern has been to shut down smaller plants (generally relegated to the "other" category in table 3), and expand production runs in the larger plants. With foreign investment and rapid growth in the industry, the number of plants producing at least 25,000 vehicles rose from 3 in 1995 to 11 in 2002.

Import and domestic shipment data in value terms for 1997, the preaccession reference point, are summarized in table 4. Reflecting relative tariff differences, imports are concentrated in parts rather than in vehicles. China's preaccession average tariff on automobile products (vehicles and parts) was 35 percent (table 5). The rate for vehicles averaged 70 percent, with sedans subject to tariffs of 80-100 percent. Parts were subject to an average tariff of 23 percent. Import shares were

3. There are strong parallels to the situation in Mexico before the North American Free Trade Agreement (Lopez de Silanes and others 1994), where protected, inefficient factories operated well within the global technology frontier. 


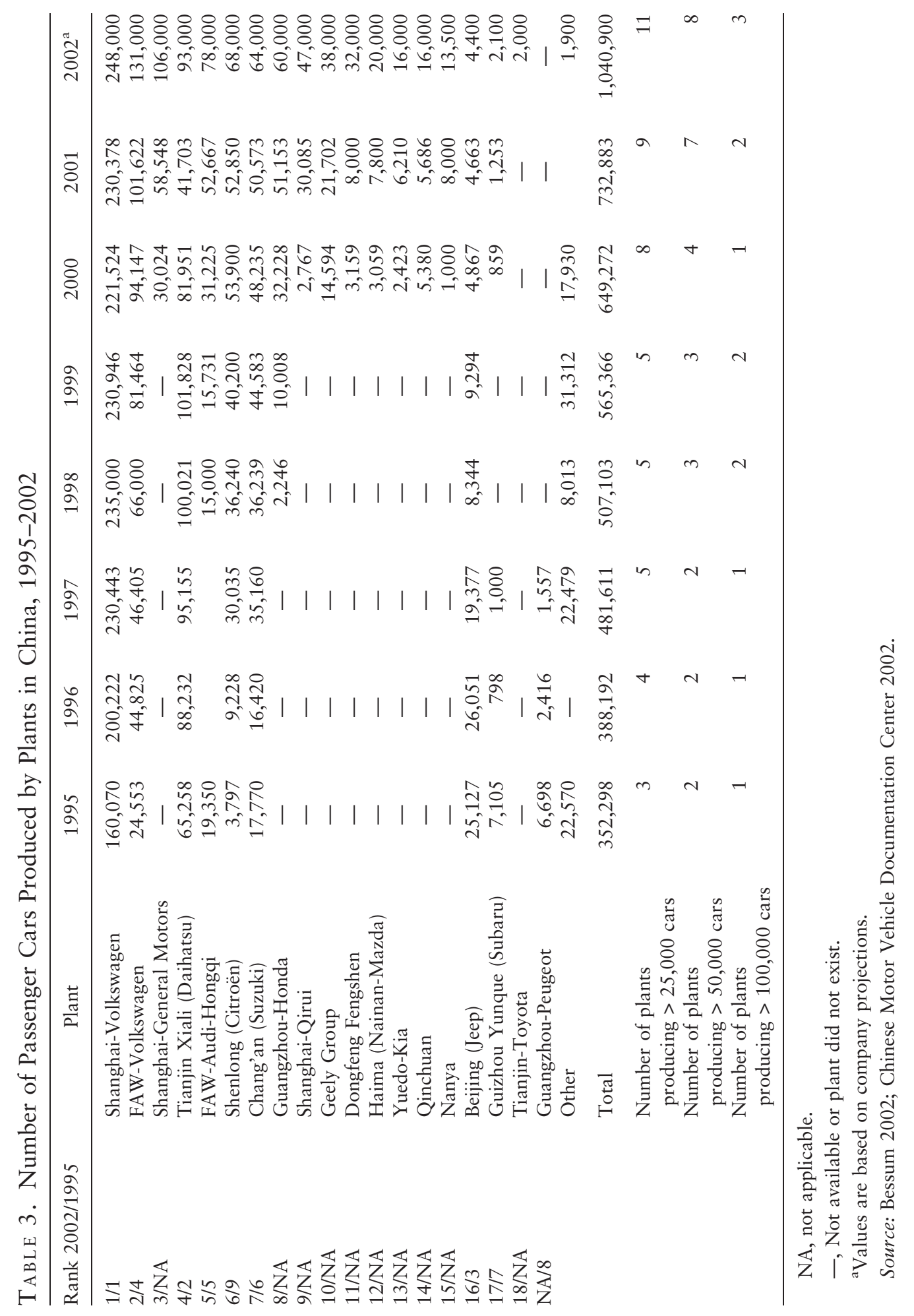


TAв Le 4. China's Motor Vehicle Industry before World Trade Organization Accession, 1997 (millions US\$)

\begin{tabular}{lr}
\hline Sector & Amount \\
\hline Imported motor vehicles and parts, world prices & $3,607.7$ \\
Imported motor vehicles and parts, internal prices & $4,849.3$ \\
Imported parts & $3,239.5$ \\
Imported motor vehicles & $1,609.9$ \\
Domestic motor vehicles, intermediates, and parts & $32,812.5$ \\
Intermediates and parts & $10,896.2$ \\
Industry consumption of motor vehicles & $21,625.5$ \\
Final consumption of motor vehicles & 290.8 \\
\hline
\end{tabular}

Source: McDougall 2001.

Table 5. Tariffs on Motor Vehicles in China (percent)

\begin{tabular}{lcc}
\hline Item & 1997 rate & Final rate \\
\hline Finished motor vehicles & 71 & 25 \\
Motor vehicle parts & 23 & 10 \\
Electronic parts & 12 & 10 \\
Average motor vehicles and parts & 35 & 15 \\
\hline
\end{tabular}

Source: China wTO accession schedule, GTAP data, and Office of the U.S. Trade Representative.

relatively low, averaging perhaps 3 percent during 1995-2002. Officially, only 20,000 sedans were imported, though many more were likely smuggled into the country. ${ }^{4}$ Official policy encouraged the use of domestic parts and favored locally (regionally) produced parts. Domestic content rules applied to new investments, stipulating 80 percent domestic content by the third year. The effects of these policies are reflected in the low share of imported automotive parts imports in total production. Even after China's completion of wTO accession, foreign ownership will be limited to 50 percent. ${ }^{5}$

Tariff rates are scheduled to come down substantially as part of the wTO accession process: by 25 percent on vehicles and 10 percent on parts on a most favored nation basis. Quotas will be phased out by 2006 and will be reduced by 15 percent a year until then. Domestic content requirements have already been removed. (Both of these nontariff barriers violate basic wTO rules.) Other WTO obligations imply free movement of imported automobiles (free of import quotas)

4. Unofficial estimates (based on interviews) are that 100,000 or more sedans have been imported in recent years. Many smuggled cars are luxury models.

5. In the past, finding partners often meant having to go to provinces other than those on the coast. These provinces often tried to ensure that "buy local" conditions prevailed. In the case of taxis in Shanghai, regulations stipulated specifications that could be filled only by a Volkswagen model. 
within the Chinese market. The internal barriers to trade simply cannot be sustained if China's new WTO obligations are to be taken seriously. All these changes in the structure of protection imply tremendous pressure for a breakdown of internal barriers for domestic production and for rationalization of the domestic industry.

The government realizes the implications for the structure of the automotive sector. Official and industry sources indicate an intention to support only a small number of domestic production groups, perhaps including the Shanghai group (Volkswagen), China First Auto Works (Volkswagen), Shanghai GM (Buick), and the Dongfeng Group (Citroën). These groups with their foreign partners already account for more than 70 percent of production in China. Such a sharp rationalization will undoubtedly be painful, but it could allow the industry to consolidate production and work its way down the average cost curve for vehicle production.

\section{The Modeling Framework}

A CGE model is used to assess the possible impact of China's accession to the WTO. (More technical details and references for the model are provided in Francois and Spinanger 2001 and in the technical annex available for download with the model files. ${ }^{6}$ ) CGE models have become a standard approach for analysis of multisector policy initiatives, such as the accompanying wTO accession (Francois 2000). Although the exercises are hampered by both the necessary assumptions and the quality of available data, their estimates of the direct and indirect impact of broad policy changes have proved helpful for assessing existing economic policies and formulating new ones.

\section{The Model Data}

The data come from a number of sources. They are organized into 23 sectors and 25 regions (table 6). Details on the value-added chain linking fibers into textiles and clothing production are included to better capture the initial impact on the base scenario of the Agreement on Textiles and Clothing (ATC), which is scheduled to phase out the remaining textile and clothing quotas by 2005 .

Data on production and trade are based on national accounting data linked through trade flows and drawn directly from the Global Trade Analysis Project (GTAP) version 5 dataset (McDougall 2001). The dataset is benchmarked to 1997 and includes detailed data on national input-output, trade, and final demand structures. The basic database was updated to better reflect actual import protection for goods and services.

Basic data on current tariff rates come from UN Conference on Trade and Development and wTO data on the schedules of applied and bound tariff rates.

6. The model files, along with the technical annex describing the model, can be downloaded from www.intereconomics.com/francois. The model is implemented in GEMPACK. 
Table 6. The Regional and Sectoral Breakdown of the CGE Model

\begin{tabular}{|c|c|}
\hline Region & Sector \\
\hline & Primary \\
\hline Hong Kong, China & Wool \\
\hline People's Republic of China & Natural fibers \\
\hline Taiwan, China & Primary food production \\
\hline Japan & Other primary production \\
\hline Korea, Rep. of & Sugar \\
\hline ASEAN $5^{\mathrm{a}}$ & Processed food, tobacco, and beverages \\
\hline Vietnam & Manufacturing \\
\hline India & Textiles \\
\hline Bangladesh & Wearing apparel \\
\hline Other South Asian economies ${ }^{\mathrm{b}}$ & Leather products \\
\hline Australia & Chemicals, refinery products, rubber, plastics \\
\hline New Zealand & Steel refinery products \\
\hline Canada & Nonferrous metal products \\
\hline United States & Motor vehicles and parts \\
\hline Mexico & Electronic machinery and equipment \\
\hline Brazil & Other machinery and equipment \\
\hline MERCOSUR $^{c}$ & Other manufactured goods \\
\hline Caribbean Basin Initiative economies $^{\mathrm{d}}$ & Services \\
\hline Andean Trade Pact economies ${ }^{\mathrm{d}}$ & Wholesale and retail trade services \\
\hline Chile $^{\mathrm{d}}$ & Transportation services (land, water, air) \\
\hline Other Latin America $^{\mathrm{d}}$ & Communications services \\
\hline European Union, 15 economies & Construction \\
\hline Turkey & Finance, insurance, and real estate services \\
\hline Africa and the Middle East & Other commercial services \\
\hline Rest of world & Other services \\
\hline
\end{tabular}

${ }^{a}$ Indonesia, Malaysia, Philippines, Singapore, and Thailand.

${ }^{\mathrm{b}}$ Nepal, Pakistan, and Sri Lanka.

'Includes Argentina, Paraguay, and Uruguay. Brazil is represented separately.

${ }^{\mathrm{d}}$ Not treated in tables and diagrams.

Source: Database aggregation produced by authors.

These are integrated into the core GTAP database. They are supplemented with data from the Office of the U.S. Trade Representative and the U.S. International Trade Commission on regional preference schemes in the Western Hemisphere. Data on agricultural protection, as integrated into the GTAP core database, are based on estimates by the Organisation for Economic Co-operation and Development and U.S. Department of Agriculture. Estimates on tariffs and nontariff barriers are further adjusted to reflect remaining Uruguay Round commitments, including the phase-out of textile and clothing quotas under the ATC. Data on post-Uruguay Round tariffs are from recent estimates reported by Francois and Strutt (1999), which come primarily from the wTO's integrated database, with supplemental information from the World Bank's recent assessment of detailed pre- and post-Uruguay Round tariff schedules. All this tariff information has been matched to the current model sectors. Services trade barriers are based on 
the estimates described in the technical annex and are shown in table 7 (the basic GTAP database includes no information on trade barriers for services, for example).

The basic GTAP dataset is benchmarked to 1997 and reflects applied tariffs in place in 1997. Because the interest here is with the post-Uruguay Round world, a "pre-experiment" was run on the model to implement the remaining Uruguay Round tariff cuts. Most of these cuts were already in place in the 1997 benchmark

Table 7. China's Tariff Rates before and after World Trade Organization Accession, as Modeled (percent)

\begin{tabular}{lrcr}
\hline Sector & Model base rates & Accession rates & New bound rates \\
\hline Merchandise & & & \\
Wool & 14.8 & 42.0 & 38.0 \\
Natural fibers & 3.1 & 17.4 & 13.6 \\
Primary food production & 58.8 & 58.1 & 46.8 \\
Other primary production & 0.5 & 6.9 & 5.0 \\
Sugar & 29.5 & 30.0 & 20.0 \\
Processed food, tobacco, & 37.7 & 40.7 & 23.2 \\
$\quad$ and beverages & & & \\
Textiles & 25.1 & 25.4 & 10.2 \\
Wearing apparel & 31.8 & 32.8 & 16.1 \\
Leather products & 12.1 & 20.9 & 17.0 \\
Chemicals, refinery products, & 12.6 & 14.9 & 7.2 \\
$\quad$ rubber, plastics & & & \\
Steel refinery products & 9.7 & 8.9 & 5.1 \\
Nonferrous metal products & 7.8 & 8.2 & 5.5 \\
Motor vehicles and parts & 34.4 & 38.7 & 15.4 \\
$\quad$ Motor vehicles & 70.5 & 70.5 & 25.0 \\
$\quad$ Parts & 23.4 & 23.4 & 10.0 \\
Electronic machinery and equipment & 11.9 & 16.9 & 9.6 \\
Other machinery and equipment & 12.8 & 15.4 & 10.1 \\
Other manufactured goods & 14.5 & 22.0 & 16.3 \\
Services & & & \\
Wholesale and retail trade services & 0.0 & NA & 0.0 \\
Transportation services & 4.0 & NA & 2.0 \\
$\quad$ (land, water, air) & & & \\
Communications services & 9.2 & NA & 4.6 \\
Construction & 13.7 & NA & 6.8 \\
Finance, insurance, and real & 8.1 & NA & 4.0 \\
$\quad$ estate services & & NA & 24.0 \\
Other commercial services & 48.0 & & 13.0 \\
Other services & 25.7 & & \\
\hline & & & \\
\hline & & & \\
\hline
\end{tabular}

NA, not applicable.

Note: Service barriers are based on gravity equation estimates. Accession rates reflect an assumed 50 percent drop in cross-border trading costs.

Source: China wTO accession schedule, GTAP data, and Office of the U.S. Trade Representative. Gravity estimates are based on trade and macroeconomic data and cross-country regressions; see Francois and Spinanger 2001. 
dataset. The data were also adjusted to reflect regional preference schemes in Latin America (not represented in the core GTAP database). The dataset used for actual policy experiments is therefore a representation of a notional world economy (with values in 1997 dollars) with full Uruguay Round tariff cut implementation. Experiments consider both the ATC phase-out and China's WTO accession, with reference to this post-Uruguay Round tariff benchmark.

\section{Model Structure}

Except for the automobile sector, the CGE model structure is standard. On the production side, firms in all sectors minimize costs, employing domestic factors of production (capital, labor, and land) and intermediate inputs from domestic and foreign sources to produce goods and services. Technologies are modeled as constant elasticity of substitution processes defined over primary inputs and Leontief processes defined over intermediate inputs. Products from different regions are assumed to be imperfect substitutes in accordance with the Armington assumption. Prices on goods and factors adjust until all markets are simultaneously in (general) equilibrium-all markets clear. Although changes are modeled in gross trade flows, changes in net international capital flows are not (this does not preclude changes in the level of gross capital flows). Trade liberalization in the goods sectors involves reduction of tariffs and a shift from model base rates to the new bound rates. The new bound rates are generally quite close to the calculations of average accession rates. Liberalization in the service sector is modeled as a reduction in trading costs, reflecting the barrier reductions in barriers reported in table 7 . These are Samuelson iceberg costs.

To reflect the status quo in the motor vehicle sector in a stylized, though representative way, one option was to implement imperfect competition in the model. This was rejected, however, because it does not adequately reflect the primary issue at hand. Government policy has certainly resulted in market segmentation, but there is also price setting and regulation. The choice was made to focus on realized cost efficiency for the sector. The cost structure of the industry reflects the net effect of a basket of policies. Like clothing in India or automobiles in Mexico before the North American Free Trade Agreement, the structure of the automobile sector in China reflects regulated efficiency-the impact of the general regulatory and administrative environment. The critical issue is thus these collective inefficiencies, which follow from the full set of industrial policies. At the same time, an implication of intended public policy seems to be restructuring and consolidation, leading to an improvement in regulated efficiency.

What shape will the gains from changes in regulated efficiency take? Through rationalization, the industry may collectively move down relevant cost curves. Although minimum efficient scale for some models is about 200,000 units per plant (Huang 2002), a global norm, based on comparisons with plant sizes in North America and Europe, is closer to 350,000 units. Further comparison of current plant scale in China (see table 3 ) with such a norm implies that average 
costs are roughly 20 percent higher simply because of inefficient scale. ${ }^{7}$ Data from interviews with industry representatives (Feenstra and others 2001) point to similar cost savings, with expectations of even higher cost reductions in the range of 25-30 percent. A World Bank study (1993, p. 57) describes quite succinctly the expected gains from reaching minimum efficient scale (MES): "If this cost-volume relationship is applied to the Chinese automotive industry, the passenger car segment has a cost disadvantage of 20 to 30 percent compared with the international producers having MES. This cost disadvantage could be an understatement, however, as there are already eight producers in the market."

This net cost effect is stressed here and sets the treatment of motor vehicles apart from that of other sectors in the model. The lower bound of these cost effect estimates is used. In particular, the focus is on potential cost savings in the final assembly of automobiles due to a higher regulated efficiency level for the industry, resulting from consolidation and rationalization of policy. ${ }^{8}$ In addition, the differential treatment of parts and finished vehicles in the tariff schedule is also tracked.

That large gains can be achieved by rationalizing production and reducing costs was clearly demonstrated in the United States at the beginning of the twentieth century (figure 2). In 1914, “13,000 workers at Ford were producing 260,720 cars. By comparison, in the rest of the industry, it took 66,350 workers to make 286,770" cars. ${ }^{9}$ Such dichotomies also exist across the spectrum of production possibilities in China today, with new foreign-built modern plants coexisting with Mao-era facilities. Similar demand factors also prevailed. As a result of Ford's new production methods, cars in the United States moved from being scarce goods to goods affordable by large segments of the population. China is already moving into this phase. The similarity between China's motor vehicle production from 1984 to 2002 and that of the United States between 1900 and 1924, as shown in figure 2, would seem to justify such an analogy.

\section{Experiments And Results}

The experiments involve full accession for China and Taiwan, China. The basic accession package involves the changes in tariffs detailed in table 7. For automobiles the following effects are modeled:

- Tariffs on motor vehicles decrease to 25 percent.

- Tariffs on automobile parts are phased down from an average of 23.4 percent to an average of 10 percent.

7. The 20 percent figure is based on the distribution of current plants shown in table 3 . An average cost index for the industry can be calculated by applying the formula $\Delta \ln ($ Average Cost $)=$ $C D R \cdot \Delta \ln ($ Quantity), where $C D R$ is the inverse elasticity of scale, defined as $C D R=($ Average Cost Marginal Cost)/Average Cost, and is between 0.125 and 0.135 (the range of values found in engineering studies). If the index is 100 at 350,000 units per plant, current plant structure yields a cost index of roughly 120 .

8. In other words, cost savings are modeled at the assembly level.

9. See www.wiley.com/products/subject/business/forbes/ford.html. 
Figure 2. Annual Motor Vehicle Production in China and the United States (thousands)

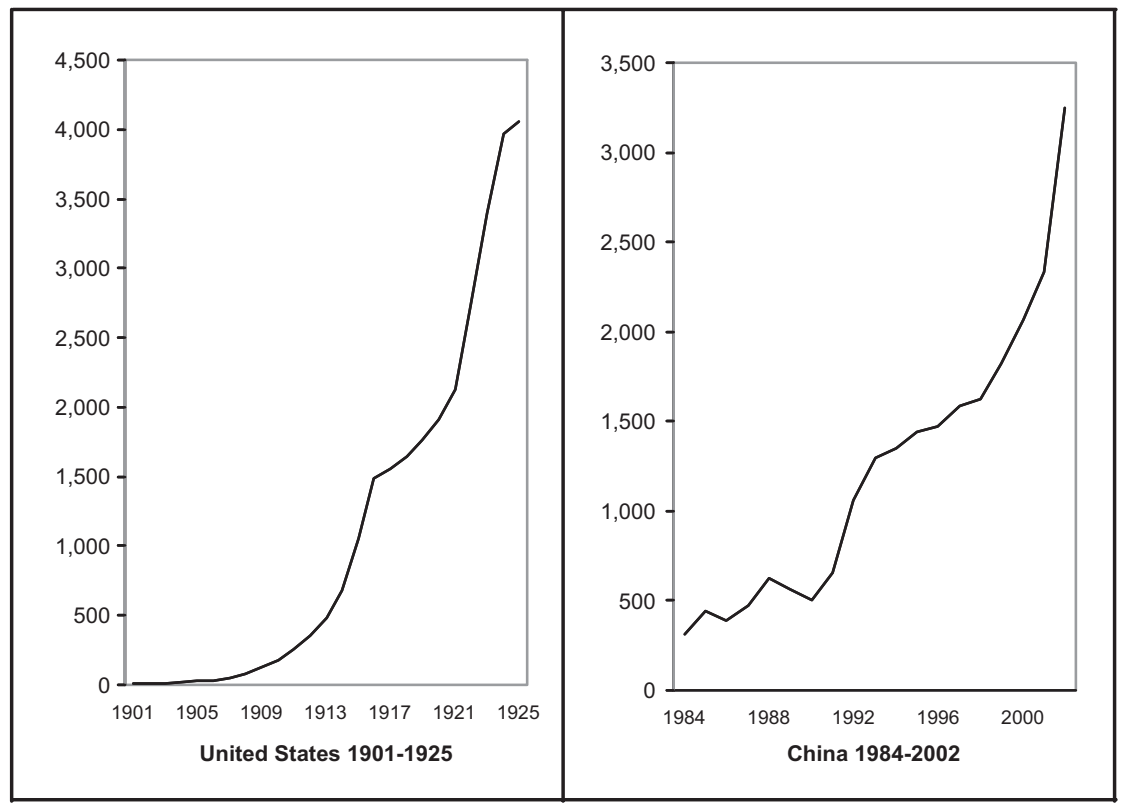

Source: Bessum (2002) and Verband der Automobilindustrie (various issues).

- The industry is rationalized. Implicitly, this involves elimination of internal regional barriers and consolidation within the domestic market. Small, inefficient factories close. To quantify this effect, sedan production is taken as representative. Given the typical scale of domestic production, automobile plants are assumed to realize a 20 percent cost savings in assembly if they move to efficient scale. (See note 2 and the discussion in section II). This savings is modeled at the assembly level.

The overall sectoral impacts of the experiments are presented in table 8, which reports changes in the quantity of output under alternative scenarios. Extending the ATC phase-out to China and Taiwan implies a dramatic expansion in the textile and clothing sectors, with textiles growing 14 percent and clothing 50 percent. There are important general equilibrium effects, as the resources needed for this experiment are drawn from other parts of the economy, including the motor vehicle sector.

Especially important for the motor vehicle sector are the results reflecting the incremental impact of China's market access commitments made as part of WTO accession and shown in columns $\mathrm{B}$ and $\mathrm{C}$ of table 8 . Column $\mathrm{B}$ is a business as usual scenario, without restructuring. It reflects a domestic motor vehicle 
TAble 8. Impact on Output of World Trade Organization Accession by China and Taiwan, China (percentage change)

\begin{tabular}{|c|c|c|c|c|c|}
\hline Sector & $\begin{array}{l}\text { Elimination } \\
\text { of textile } \\
\text { and apparel } \\
\text { quotas } \\
\text { A }\end{array}$ & $\begin{array}{c}\text { Accession } \\
\text { without } \\
\text { automobile } \\
\text { sector } \\
\text { restructuring } \\
\text { B }\end{array}$ & $\begin{array}{c}\text { Accession } \\
\text { with automobile } \\
\text { sector } \\
\text { restructuring } \\
\text { C }\end{array}$ & $\begin{array}{c}\text { Total impact } \\
\text { without } \\
\text { automobile } \\
\text { sector } \\
\text { restructuring } \\
\mathrm{D}=\mathrm{A}+\mathrm{B}\end{array}$ & $\begin{array}{c}\text { Total } \\
\text { impact with } \\
\text { automobile } \\
\text { sector } \\
\text { restructuring } \\
\text { E = A + C }\end{array}$ \\
\hline Wool & 12.8 & 18.3 & 16.8 & 33.4 & 31.8 \\
\hline Other natural fibers & 12.1 & 17.9 & 16.4 & 32.1 & 30.5 \\
\hline Primary food & -0.4 & -1.0 & -0.9 & -1.5 & -1.3 \\
\hline $\begin{array}{l}\text { Other primary } \\
\text { production }\end{array}$ & -2.6 & -3.6 & -3.3 & -6.1 & -5.8 \\
\hline Sugar & -2.3 & -7.9 & -8.5 & -10.0 & -10.6 \\
\hline Processed foods & -1.0 & -4.7 & -4.7 & -5.6 & -5.7 \\
\hline Textiles & 13.9 & 32.0 & 30.6 & 50.4 & 48.8 \\
\hline Clothing & 50.3 & 75.5 & 73.0 & 163.7 & 160.0 \\
\hline Leather goods & -7.2 & 5.4 & 3.5 & -2.2 & -3.9 \\
\hline $\begin{array}{l}\text { Chemicals, rubber, } \\
\text { and refineries }\end{array}$ & -2.0 & -4.5 & -4.3 & -6.5 & -6.2 \\
\hline Primary steel & -4.0 & -9.1 & -7.9 & -12.8 & -11.5 \\
\hline $\begin{array}{l}\text { Primary nonferrous } \\
\text { metals }\end{array}$ & -5.4 & -9.2 & -8.9 & -14.2 & -13.9 \\
\hline $\begin{array}{l}\text { Motor vehicles } \\
\text { and parts }\end{array}$ & -4.1 & -36.7 & 8.0 & -39.3 & 3.5 \\
\hline Electronics & -5.1 & -3.9 & -4.4 & -8.8 & -9.3 \\
\hline $\begin{array}{l}\text { Other machinery } \\
\text { and equipment }\end{array}$ & -3.8 & -5.4 & -4.8 & -9.0 & -8.5 \\
\hline Other manufactures & -2.2 & -0.3 & 0.1 & -2.5 & -2.0 \\
\hline $\begin{array}{l}\text { Wholesale and } \\
\text { retail trade }\end{array}$ & -0.3 & 1.4 & 1.9 & 1.1 & 1.7 \\
\hline Transport services & -1.9 & -2.0 & -1.4 & -3.9 & -3.3 \\
\hline Communications & -0.5 & 0.1 & 1.0 & -0.5 & 0.5 \\
\hline Construction & 0.8 & 2.8 & 4.2 & 3.6 & 5.0 \\
\hline $\begin{array}{l}\text { Finance, insurance, } \\
\text { and real estate }\end{array}$ & -0.7 & -0.4 & 0.2 & -1.1 & -0.4 \\
\hline Commercial services & -0.8 & -5.9 & -5.4 & -6.6 & -6.2 \\
\hline Other services & 0.0 & 0.5 & 1.2 & 0.5 & 1.2 \\
\hline
\end{tabular}

Source: Model estimates; see table 7.

industry that continues to be fragmented, with favored producers in each region, small production runs, and high costs. Such an industry is simply unable to compete with imports. It is hit very hard by imports, with domestic production falling 37 percent. Combined with the initial impact of the ATC phase-out, there is a dramatic retrenchment of the uncompetitive domestic industry in the face of imports (column D).

By contrast, the scenario with elimination of internal barriers, rationalization of plants (with smaller plants being closed), and an efficiency gain of roughly 
20 percent as scale economies are realized, production rises slightly ( 3 percent) and the industry emerges as relatively competitive, despite the loss of protection (columns $\mathrm{C}$ and $\mathrm{E}$ ).

The most striking difference between the two scenarios is in the impacts on intermediate parts production and final automobile production (table 9). Under the scenario of business as usual, imports of parts rise slightly, whereas their share of the domestic market rises substantially. There is a dramatic surge in imports of motor vehicles, which displace more than a third of domestic production. There is a drop in the overall market for parts because of the decline in domestic vehicle production. Under the second scenario of rationalization of the final assembly sector, which allows the sector to compete more directly with imports, there is a shift to imported intermediates (rising to a market share of more than 50 percent), a fall in domestic parts production (displaced by imports), and steady overall demand for parts. Although ground is lost to parts imports, sales of domestic vehicles remain steady in the face of imports.

China's wTO accession also affects value added and trade. It is logical to expect some export response, both because of the general liberalization in trade

TABle 9. Impact of World Trade Organization Accession by China and Taiwan, China, on China's Motor Vehicle Market

\begin{tabular}{|c|c|c|c|}
\hline Item & $\begin{array}{l}\text { Benchmark } \\
1997\end{array}$ & $\begin{array}{c}\text { Accession } \\
\text { without } \\
\text { automobile } \\
\text { sector } \\
\text { restructuring }\end{array}$ & $\begin{array}{c}\text { Accession with } \\
\text { automobile } \\
\text { sector } \\
\text { restructuring }\end{array}$ \\
\hline \multicolumn{4}{|l|}{ Value (millions of 1997 U.S. dollars) } \\
\hline $\begin{array}{l}\text { Imported motor vehicles } \\
\text { and parts, world prices }\end{array}$ & $3,607.7$ & $10,595.7$ & $6,968.0$ \\
\hline $\begin{array}{l}\text { Imported motor vehicles } \\
\text { and parts, internal prices }\end{array}$ & $4,806.4$ & $12,080.7$ & $7,995.7$ \\
\hline Imported parts & $1,609.9$ & $2,827.9$ & $5,535.2$ \\
\hline Imported motor vehicles & $3,196.5$ & $9,252.8$ & $2,460.5$ \\
\hline $\begin{array}{l}\text { Domestic automobiles, } \\
\text { intermediates, and parts }\end{array}$ & $32,812.5$ & $19,401.9$ & $24,249.6$ \\
\hline Intermediates and parts & $10,896.2$ & 4,494.0 & $5,189.1$ \\
\hline $\begin{array}{l}\text { Industry consumption of motor } \\
\text { vehicles }\end{array}$ & $21,625.5$ & $14,698.8$ & $18,785.0$ \\
\hline Final consumption of motor vehicles & 290.8 & 209.2 & 275.4 \\
\hline \multicolumn{4}{|l|}{ Index and share } \\
\hline $\begin{array}{l}\text { Import share of total } \\
\text { automobile parts (percent of value) }\end{array}$ & 12.9 & 38.6 & 51.6 \\
\hline Index of vehicle production & 100.00 & 68.0 & 102.8 \\
\hline Index of parts production & 100.00 & 41.2 & 56.3 \\
\hline
\end{tabular}

Source: McDougall 2001 (baseline) and authors' model estimates (impact). 
Table 10. China's Export Shares, Baseline and Two Scenarios

\begin{tabular}{lccc}
\hline Sector & $\begin{array}{c}\text { Total impact } \\
\text { without } \\
\text { automobile } \\
\text { sector } \\
\text { restructuring }\end{array}$ & $\begin{array}{c}\text { Total impact } \\
\text { with } \\
\text { automobile } \\
\text { sector } \\
\text { restructuring }\end{array}$ \\
\hline Primary & 0.046 & 0.033 & 0.033 \\
Textiles & 0.084 & 0.098 & 0.097 \\
Wearing apparel & 0.102 & 0.303 & 0.298 \\
Motor vehicles and parts & 0.006 & 0.004 & 0.019 \\
Electronic machinery and equipment & 0.133 & 0.100 & 0.099 \\
Other machinery and equipment & 0.146 & 0.104 & 0.103 \\
Other manufactured goods & 0.397 & 0.294 & 0.290 \\
Services & 0.087 & 0.062 & 0.062 \\
\hline
\end{tabular}

Source: McDougall 2001 (baseline) and authors' model estimates (impact).

and because pressure from imports may force firms to seek other markets. China exports less that 4 percent ( $\$ 1.3$ billion of production of $\$ 32$ billion) of its production in the sector based on 1997 values. To put this in perspective, Australia has a comparable level of exports with an industry only one-third the size of China's. The Republic of Korea's export share is 10 times as large. China's trade is therefore well below global integration standards, measured by exports.

The model experiments show that restructuring accelerates the export orientation of the automobile industry, with a rapid growth in exports (table 10). Exports rise by roughly $\$ 3.8$ billion, or 300 percent, reaching roughly 10 percent of production by value. Although this seems dramatic, it needs to be kept in perspective. Automobiles and parts are a small share of exports (0.6 percent in 1997) and remain small (up to 2 percent) even with the growth in automobile exports. Most of the restructuring remains focused on the domestic market.

\section{Summary and Conclusions}

Regulatory reform and internal restructuring are critical to the impact of wTO accession on China's motor vehicle sector. Such restructuring is represented here by a cost reduction following from consolidation and rationalization. This representation is supported by a comparison of scale in a typical automobile plant in China to that in typical plants in North America or Europe and also by firm survey responses. It is also supported by earlier estimates of the benefits from achieving minimum and efficient scale and radical restructuring to improve production efficiency. The net result is a movement of costs toward global norms. With restructuring, the final assembly industry can become competitive by world standards, while the parts industry further integrates 
with the global industry through exports (and through higher imports). Without such restructuring, however, the domestic industry remains uncompetitive, and WTO accession means that imports of final vehicles will surge, though imports of parts will fall as production moves offshore.

Viewed in total, what do the results show? They highlight the importance of incorporating the impact of regulatory regimes on costs when assessing the impact of changes in trade policy. For China, restructuring within the domestic market results in a qualitatively different impact from tariff reductions. Without such restructuring, the industry fails to compete and contracts dramatically. However, with restructuring, the final assembly industry can be made internationally competitive. In addition, the industry shifts to local assembly, with high import content for domestic vehicles.

Two additional issues need to be raised. The first concerns China's population to motor vehicles ratio, which is far higher than that in many other countries with similar income levels (see table 1). Because this reflects the impact of existing policies, a significant change in policies could shift demand closer to a normal pattern of consumption, given China's geographic attributes. The second issue concerns further strengthening of demand for cars through better access to financing. Roughly 75 percent of U.S. and European automobile purchases are financed through loans, but only 15 percent of automobile purchases in China are financed this way. Although China's protocol of accession to the WTO stipulates that automobile finance will be liberalized, only draft legislation has been presented to date. ${ }^{10}$ To the extent that this potential demand can be tapped, the pressure on firms to be more productive and thus more competitive will be all the greater. This would be another factor helping ensure that the calculated welfare gains will come about.

The shortcomings of the analysis also need to be highlighted. The model applied here is very stylized, although it widely captures the real world. Although restructuring has positive overall implications for the industry, there are bound to be adjustment costs that are not pointed to in the model. Even if value added is preserved within the sector, there will likely be a dramatic relocation of jobs toward a limited number of plants, with job losses in the other, smaller plants. The current regional scattering of final automobile production (table 11) will be replaced by a more geographically concentrated pattern. Parts production will also tend to concentrate. To the extent that parts suppliers are able to supply regional markets, this is likely to mean that existing clustering in coastal regions will intensify, with parts shipments to Japan, the Republic of Korea, the United States, and other regional centers of

10. Nonetheless, some major car companies (Volkswagen and Ford) did reach agreements with Chinese banks earlier this year (KPMG 2003, p. 7). According to the International Herald Tribune (October 6, 2003) China has opened up this sector in line with its wTO commitments. 
Table 11. Location of Automobile Production in China, 2002

\begin{tabular}{|c|c|c|c|}
\hline \multicolumn{4}{|c|}{ Foreign production } \\
\hline Producer & Foreign producer & Capacity (cars/year) & Production \\
\hline 1 SAIC VW & Volkswagen & 450,000 & 278,890 \\
\hline 2 SAIC GM & General Motors & 100,000 & 111,623 \\
\hline 3 FAW VW & Volkswagen & 270,000 & 158,654 \\
\hline 4 FAW Toyota & Toyota/Mazda & 70,000 & 30,165 \\
\hline 5 Dongfeng PSA & PSA/Citroën & 150,000 & 84,378 \\
\hline 6 Dongfeng Honda & Honda & 60,000 & 59,024 \\
\hline 7 Dongfeng Yulong & Nissan/Yulong & 60,000 & 38,897 \\
\hline 8 Tianjing Toyota & Toyota & 30,000 & 2,147 \\
\hline 9 JIangsu Nanya & Fiat & 100,000 & 23,393 \\
\hline 10 SAIC Chery & Daewoo & 60,000 & 49,397 \\
\hline 11 Zehjiang Jili & Daewoo (geplant) & 150,000 & 47,443 \\
\hline 12 Chongqing Chang'an Suzuki & Suzuki/Yanjin & 150,000 & 67,846 \\
\hline 13 Chang'an Ford & Ford & 50,000 & NA \\
\hline 14 Dengfeng Yueda Kia & Kia & 50,000 & 20,080 \\
\hline 15 FAW Hainan & Mazda & 50,000 & 11,989 \\
\hline 16 Beijing Hyundai & Hyundai & 30,000 & 1,356 \\
\hline 17 China Guizhou Aviation Ind. & Wanhong/Chenchang & 10,000 & 1,831 \\
\hline 18 Shenyang Brilliant Junbei & BMW (by mid-2003) & 200,000 & NA \\
\hline 19 Harbin Hafei & Mitsubishi & 30,000 & 14,577 \\
\hline 20 Shangdong Yantei & General Motors & 50,000 & NA \\
\hline 21 Southeast & Zhonghua & 60,000 & 16,935 \\
\hline 22 Beijing Jeep & Daimler-Chrysler & 85,000 & 9,052 \\
\hline 23 Jinbei General Motors & General Motors & 30,000 & 3,751 \\
\hline 24 Hunan Changfeng & Mitsubishi & 30,000 & 15,067 \\
\hline 25 Zhengzhou Nissan & Nissan & 30,000 & NA \\
\hline 26 Rongcheng Huatai & Hyundai & 20,000 & NA \\
\hline 27 Jiangxi Fuqi & Golden Lion & 20,000 & NA \\
\hline 28 Tianjing Huali & Golden Lion & 20,000 & NA \\
\hline 29 SAIC GM Wuling & General Motors & 150,000 & NA \\
\hline 30 Sanjiang Renault & Renault & 30,000 & NA \\
\hline 31 Chengdu FAW & Toyota & 5,000 & NA \\
\hline 32 Yizhong & SAIC/RDS & 10,000 & NA \\
\hline
\end{tabular}

(Continued)

production. ${ }^{11}$ From an employment perspective, output and value added results closely track the impact on employment. The results point to a range of effects on employment, from -40 percent without restructuring to -3 percent with restructuring. This range of effects highlights the importance of rationalizing the structure of plants.

11. European manufacturers have already established 12 plants in China, and one large U.S. company (Delphi) is shifting from Mexico. 
Table 11. Continued

\begin{tabular}{lcc}
\hline & Production capacity in provinces \\
\hline Province & Capacity (cars/year) & Production \\
\hline Anhui & 60,000 & 49,397 \\
Bejing & 115,000 & 10,408 \\
Fujian & 80,000 & 16,935 \\
Guandong & 120,000 & 97,921 \\
Guangxi Zhuang & 150,000 & $\mathrm{NA}$ \\
Guizhou & 10,000 & 1,831 \\
Hainan & 50,000 & 11,989 \\
Heilongjang & 30,000 & 14,577 \\
Henan & 30,000 & $\mathrm{NA}$ \\
Hubei & 180,000 & 84,378 \\
Jiangsu & 130,000 & 38,460 \\
Jilin & 340,000 & 188,819 \\
Liaoming & 230,000 & 3,751 \\
Shandong & 80,000 & $\mathrm{NA}$ \\
Shanghai & 550,000 & 390,513 \\
Shanxi & 50,000 & 20,080 \\
Sichuan & 205,000 & 67,846 \\
Tianjing & 50,000 & 2,147 \\
Zehjiang & 150,000 & 47,443 \\
Total & $2,380,000$ & $1,046,495$ \\
\hline Other foreign companies & 11,200 & 2 \\
\hline Bosch & & 2 \\
Kolbenschmidt & 1,500 & 2 \\
Michelin & 4,000 & Number of plants \\
ZF/Sachs & 2,100 & \\
Total & Number of employees & \\
\hline
\end{tabular}

NA, actual production was not yet available.

Source: Bessum 2002; Chinese Motor Vehicle Documentation Center 2002.

\section{REFERENCES}

Bessum, F. 2002. "Global Car Production Statistics." Online document available at www.geocities. com/motorcity/speedway/4939/carprod.html.

China Online. 2000. "How wто Membership Could Affect China’s Auto Industry.” January 5, 2000. Available at www.chinaonline.com.

Chinese Motor Vehicle Documentation Center. 2002. Catalogue of the Present Chinese Motor Car Production, 2nd ed. Aldeboarn, Netherlands.

Feenstra, R., D. Sperling, L. Branstetter, E. Harwitt, and W. Hai. 2001. "China's Entry to the wTO: A View from the Auto Industry." Working Paper, University of California, Davis..

Francois, J. F. 2000. "Assessing the Results of General Equilibrium Studies of Multilateral Trade Negotiations." Policy Issues in International Trade and Commodities Study 3. UN Conference on Trade and Development. Available online at http://192.91.247.38/tab/pubs/itcdtab4_en.pdf. 
Francois, J. F., and D. Spinanger. 2001. "Greater China's Accession to the wTo: Implications for International Trade/Production and for Hong Kong." Paper prepared for the Hong Kong Trade Development Council.

Francois, J. F., and A. Strutt. 1999. "Post Uruguay Round Tariff Vectors for GTAP Version 4.” Working Paper, Erasmus University, Rotterdam, Netherlands.

Huang, Y. 2002. "Between Two Coordination Series: Automotive Industrial Policy in China with a Comparison to Korea." Review of International Political Economy 9 (3):538-73.

KPMG. 2003. "China Automotive and Component Parts Market." Online document available at www.kpmg.com.cn/Press\%20releases/KPMG_China_auto_industry_report03.pdf.

Lopez de Silanes, F., J. Markusen, and T. F. Rutherford. 1994. "Complementarity and Increasing Returns in Intermediate Inputs." Journal of Development Economics 45:133-51.

McDougall, R., ed. 2001. "The GTAP Database Version 5.” Working Paper, Purdue University, Global Trade Analysis Center, West Lafayette, Ind.

Verband der Automobilindustrie. Various issues. Tatsachen und Zablen. Frankfurt, Germany.

World Bank. 1993. "China Industrial Organization and Efficiency Case Study: The Automotive Sector." 12134-CHA. Washington, D.C.

World Bank. Various years. World Development Indicators. Washington, D.C.

Zhang, W., and R. Taylor. 2001. "EU Technology Transfer to China: The Automobile Industry as a Case Study.” Journal of Asia Pacific Economy 6(2):261-74. 